\title{
Base-Stock Level yang Meminimasi Biaya pada Permasalahan Single Order
}

\author{
Tanti Octavia ${ }^{1}$, Felecia $^{1}$, Grace Natalia $^{1}$
}

\begin{abstract}
The purpose of this research is to conduct an analysis on demand characteristic and inventory cost which might potentially influence the determination of base-stock level. Appropriate base-stock level will determine the maximum profit and also reduce the stockout cost for fashion products which has high demand uncertainty and single order problem. Case study is applied on a garment company with eight fashion product types that can be classified into short and long lifetime. The effect of coefficient variation, salvage price and stockout cost is analyzed towards profits and base stock level. It can be concluded that demand variability does not affect base stock level, while stockout cost and salvage price does.
\end{abstract}

Keywords: Base-stock level, single order problem

\section{Pendahuluan}

Persediaan merupakan salah satu unsur penting dalam sebuah perusahaan karena mempunyai pengaruh yang cukup besar terhadap kegiatan produksi. Penentuan persediaan sendiri sangat dipengaruhi oleh trend yang berlaku saat itu dan ketidakpastian permintaan dari waktu ke waktu (Caro dan Martinez [5]). Tingkat ketidakpastian permintaan dari produk sangatlah bervariasi bergantung pada jenis produk yang ditawarkan.

Pengaruh trend yang berlaku saat itu merupakan salah satu permasalahan single order. Single order problem dapat dibedakan menjadi 2 kondisi, yaitu: permasalahan memproduksi barang-barang yang bersifat single order (Tersine[9]); dan pembelian produk yang bersifat single order. Salah satu contoh industri yang memiliki permasalahan single order dan ketidakpastian permintaan yang tinggi adalah industri garment. Permintaan produk, khususnya produk yang dapat mengalami penurunan nilai seperti garment, dapat dipengaruhi oleh waktu, jumlah persediaan dan harga (Ajanta [1]). Pada permasalahan produksi single order harga merupakan parameter yang paling sensitif dibandingkan ketersediaan mesin dan biaya kehilangan penjualan (Widyadana dan Wee [12]). Pada contoh kasus produk fashion ZARA, penyebab ketidakpastian permintaan disebabkan oleh siklus hidup produk pendek dan kebijakan perusahaan terhadap penentuan produk yang ada di display (Caro dan Gallien [4]).

\footnotetext{
1 Fakultas Teknologi Industri, Jurusan Teknik Industri, Universitas Kristen Petra. Jl. Siwalankerto 121-131, Surabaya 60236, Indonesia, Email: tanti@petra.ac.id.
}

Diterima 14 April 2011; revisi1 30 April 2011; revisi2 15 Mei 2011, diterima untuk dipublikasikan 21 Mei 2011.
Oleh sebab itu penentuan distribusi permintaan yang tidak tepat akan berakibat resiko pencapaian profit yang tidak optimal (Vaagendan dan Wallace [10]). Keuntungan maksimum pada rantai pasok akan dapat dimaksimumkan apabila distributor yang mengendalikan keputusan jumlah pemesanan walaupun dengan resiko overstock (Webster [11]).

Ketidaktepatan dalam penentuan base-stock pada produk yang bersifat single order memiliki tingkat ketidakpastian permintaan tinggi akan mengakibatkan terjadinya kelebihan ataupun kekurangan persediaan yang pada akhirnya mengakibatkan kerugian finansial (Jinn et al. [8]). Dalam penentuan persediaan, pengaturan yang banyak dilakukan perusahaan adalah dengan memberikan jumlah persediaan yang cukup besar dalam mengantisipasi ketidakpastiaan permintaan (Berlingdan Martinez [2], Chen dan Plambeck [6]). Sebuah studi kasus dilakukan pada perusahaan garment yang memiliki demand dengan variabilitas yang tinggi dan bersifat single order. Penelitian ini dilakukan untuk menentukan jumlah base-stock yang tepat (Berling dan Martinez [2]) sehingga keuntungan dapat selalu dikendalikan agar sesuai dengan target yang ditetapkan perusahaan. Penentuan tercapai profit yang maksimal.

\section{Metode Penelitian}

\section{Single Order Problem}

Single order problem umumnya dikenal dengan Newsboy problem atau Christmas Tree problem (Tersine[10]). Single order problem biasanya dialami oleh pengecer yang menjual produk single order. Produk single order memiliki pola permintaan dengan periode penjualan atau pemakaian yang terbatas (Ajanta [1], Cachon dan Swinney [3]) dimana hanya terdapat satu kesempatan untuk pemesanan 
terhadap produk single order tersebut. Pemesanan produk single order dilakukan pada awal periode dan selama periode tersebut tidak ada kesempatan untuk melakukan pemesanan yang kedua kalinya (Caro dan Martinez [5]). Jadi, produk dipesan pada periode waktu tertentu hanya dapat digunakan untuk memenuhi permintaan selama periode tersebut (Ajanta [1]). Pada akhir periode, produk yang tidak terjual tersebut tidak bernilai.

Jumlah pemesanan yang dilakukan akan berpengaruh terhadap laba. Jika permintaan selama periode tertentu melebihi jumlah pemesanan mengakibatkan hilangnya kesempatan untuk memperoleh keuntungan, akan tetapi jika permintaan selama periode tertentu lebih kecil daripada jumlah pemesanan maka di akhir periode penjualan terjadi kelebihan stok (Chen dan Plambeck [6]). Terdapat tiga alternatif untuk sisa produk akibat kelebihan persediaan yaitu dibuang karena rusak atau usang, dijual dengan harga yang lebih murah, atau disimpan untuk musim berikutnya. Setiap alternatif tersebut mengakibatkan terjadinya biaya.

\section{Minimasi Biaya}

Coefficient of variation (cv) yang besar menjadi isu yang utama pada produk dengan lifetime yang pendek (Chen dan Plambeck[6]). Permintaan diasumsikan variabel acak non-negative dengan mean $(\mu)$ dan varians $\left(\sigma^{2}\right)$. Asumsi zero inventory akan dipergunakan untuk mempermudah penjelasan. Keuntungan yang diharapkan dengan melakukan order sebesar $y>0$ unit dapat dihitung dengan persamaan:

$$
\begin{aligned}
& \Pi(y)=(p-c) \mu-G(y) \\
& G(y)=h \mathbb{E}(y-D)^{+}+b \mathbb{E}(D-y)^{+}
\end{aligned}
$$

dimana:

$p \quad$ : harga jual per unit

$c$ : harga beli per unit

$s \quad$ : salvage price per unit

$G$ : biaya ill-will

$b=p-c+G$ : biaya stock out

$h=c-s \quad$ : biaya penyimpanan

Permasalahan yang dihadapi oleh Newsboy dalam meminimalkan $G(y)$ berupa biaya stockout $(b)$ dan biaya penyimpanan $(h)$. Pada kondisi dimana basestock level tidak sama dengan permintaan, maka $G(y)$ muncul dan memiliki minimizer yang terbatas $y^{*}$, misalnya $y$ yang terkecil seperti $P(D \leq y) \geq \beta \equiv$ $b /(b+h)$. Hal ini dikarenakan permasalahan Newsvendor seringkali dianggap sebagai permasalahan minimasi biaya. Akibatnya, analisis seringkali berhenti setelah $y^{*}$ ditemukan. Nilai $\Pi\left(y^{*}\right)$ mungkin saja negatif ketika biaya yang harus dikeluarkan Newsboy $G\left(y^{*}\right)$ lebih besar daripada laba $(p-c) \mu$.

Tiga pendekatan yang digunakan dalam meminimasikan biaya, antara lain: (Gallego et al. [7])

a. Pendekatan normal

Dalam pendekatan normal, $y^{*}$ bersifat linear pada $\sigma$ yang dapat dihitung dengan menggunakan persamaan berikut:

$$
\begin{aligned}
& y^{*}=\mu+\sigma Z_{\beta} \\
& \Pi\left(y^{*}\right)=(p-c) \mu-(h+b) \sigma \phi\left(Z_{\beta}\right)
\end{aligned}
$$

dimana $Z_{\beta}=\Phi^{-1}(\beta)$ invers dari distribusi normal.

b. Pendekatan maksimal

Pendekatan maksimal meminimasikan biaya pada distribusi non-negatif yang terburuk dengan menggunakan mean dan varians. Basestock level pada pendekatan maksimal diperoleh dari persamaan:

$y^{*}=\mu+\frac{1}{2} \sigma\left(\sqrt{\frac{b}{h}}-\sqrt{\frac{h}{b}}\right)$

Jika $\sqrt{h / b}>\sqrt{b / h}$, maka profit dihitung dengan menggunakan persamaan:

$\Pi\left(y^{*}\right)=(p-c) \mu-\sigma \sqrt{h b}$

untuk tidak melakukan pemesanan di bawah pendekatan maksimal.

c. Pendekatan lognormal

Variabel acak $D$ dikatakan memiliki distribusi lognormal dengan parameter mean $(v)$ dan standar deviasi $(\tau)$, jika $\ln (D)$ berdistribusi normal memiliki mean $(\mu)$ dan standar deviasi $(\sigma>0)$. Fungsi pembangkit moment dari distribusi lognormal adalah

$\mathbb{E}\left(D^{n}\right)=\exp \left(n \mu+\frac{n^{2} \sigma^{2}}{2}\right)$. Dari sini dapat diturunkanv $=\exp \left(\mu+\frac{\sigma^{2}}{2}\right) ; \tau^{2}=v^{2}\left(\exp \left(\sigma^{2}\right)-1\right)$, sehingga parameter $\mu=\ln v-\ln \sqrt{1+c v^{2}}$ dan $\sigma=\sqrt{\ln \left(1+c v^{2}\right)}$.

Base-stock level untuk distribusi lognormal bisa diperoleh dengan menggunakan persamaan:

$y^{*}=\mu+\sigma Z_{\beta}$

Sedangkan laba dapat diperoleh dengan menggunakan persamaan:

$\Pi\left(y^{*}\right)=(p-c) v-(h+b) v \Phi\left(\sigma-Z_{\beta}\right)+h v$

Pengumpulan data yang dilakukan meliputi permintaan produk, harga beli produk per unit, harga jual produk per unit, dan salvage price dari 8 jenis produk garment yang diklasifikasikan ke dalam produk lifetime pendek ( $<1$ tahun) dan produk lifetime panjang ( $\geq 1$ tahun). 
Pola distribusi permintaan dan koefisien variasi $(c v)$ diukur dari setiap jenis produk. Nilai $c v$ yang telah didapatkan akan dipakai untuk menghitung jumlah base-stock dan laba berdasarkan pendekatan normal, pendekatan maksimal, dan pendekatan lognormal.

Analisa sensitivitas terhadap $c v$ dilakukan dengan mengubah nilai mean dan standar deviasi secara bergantian. Sensitivitas terhadap salvage price dilakukan dengan menurunkan dan menaikkan harga beli hingga $10 \%$. Sensitivitas terhadap biaya stockout dilakukan dengan menaikkan biaya per satu kali lipat biaya stockout.

\section{Hasil dan Pembahasan}

Penelitian dilakukan terhadap delapan jenis produk garment yang memiliki lifetime pendek dan panjang, yaitu batik, baju kotak, sifon, celana panjang, celana $7 / 8$, celana $3 / 4$, baju pesta dan rok pesta. Distribusi yang sesuai untuk sebagian besar data permintaan produk adalah Lognormal dengan 3 parameter, kecuali produk celana panjang dengan distribusi Weibull dengan 3 parameter. Nilai estimasi untuk masing-masing distribusi untuk tiap produk dapat dilihat pada Tabel 1.

Dari parameter distribusi ini dapat dianalisa bahwa baju pesta memiliki fluktuasi permintaan yang paling kecil yaitu 0,91. Sebaliknya, fluktuasi permintaan untuk sifon merupakan yang paling tinggi yaitu 2,93 sehingga risiko yang ditanggung pemilik toko dalam menjual sifon juga merupakan yang paling tinggi.

Perhitungan terhadap biaya yang dikeluarkan toko atas jumlah pemesanan optimal sebesar $y^{*}$ memerlukan komponen biaya stockout (b) dan biaya penyimpanan $(h)$. Penghitungan biaya stockout dan biaya penyimpanan masing-masing jenis produk membutuhkan data harga jual, harga beli, dan salvage price per unit.

Pada Tabel 3 ditunjukkan bahwa distribusi permintaan produk garment tidak berpengaruh terhadap keputusan pendekatan terbaik untuk digunakan dalam menentukan jumlah base-stock suatu produk. Faktor yang diduga berpengaruh terhadap pemilihan pendekatan terbaik dalam menentukan basestock level suatu produk adalah cv permintaan, salvage price produk, dan biaya stockout. Oleh karena itu, dilakukan analisis sensitivitas pendekatan distribusi terhadap per-ubahan $c v$ permintaan, salvage price produk, dan biaya stockout.

Analisa sensitivitas laba pada setiap pendekatan distribusi akan dilakukan terhadap perubahan $c v$, salvage price produk, dan biaya stockout.
Tabel 1. Mean, Standar Deviasi, dan $c v$ setiap Jenis Produk

\begin{tabular}{lrcc}
\hline \multicolumn{1}{c}{ Jenis Produk } & \multicolumn{1}{c}{ Mean } & Standar Deviasi & $\mathrm{Cv}$ \\
\hline Batik & 16,20 & 34,67 & 2,14 \\
Baju Kotak & 5,13 & 5,55 & 1,08 \\
Sifon & 4,97 & 14,58 & 2,93 \\
Celana Panjang & 41,57 & 45,40 & 1,09 \\
Celana 7/8 & 11,03 & 27,91 & 2,53 \\
Celana $3 / 4$ & 8,30 & 20,76 & 2,50 \\
Baju Pesta & 11,67 & 10,64 & 0,91 \\
Rok Pesta & 12,07 & 11,18 & 0,93 \\
\hline
\end{tabular}

Tabel 2. Komponen Biaya setiap Jenis Produk (dalam Ribuan Rupiah)

\begin{tabular}{lrrrrr}
\hline \multicolumn{1}{c}{ Jenis Produk } & $\begin{array}{c}\text { Harga } \\
\text { Jual }\end{array}$ & $\begin{array}{c}\text { Harga } \\
\text { Beli }\end{array}$ & $\begin{array}{c}\text { Salvage } \\
\text { price }\end{array}$ & \multicolumn{1}{c}{$b$} & \multicolumn{1}{c}{$h$} \\
\hline Batik & 55 & 35 & 0 & 20 & 35 \\
Baju kotak & 135 & 105 & 0 & 30 & 105 \\
Sifon & 80 & 60 & 0 & 20 & 60 \\
Celana panjang & 145 & 115 & 114,99 & 30 & $\sim 0$ \\
Celana 7/8 & 135 & 110 & 109,99 & 25 & $\sim 0$ \\
Celana 3/4 & 127,5 & 105 & 104,99 & 22,5 & $\sim 0$ \\
Bajupesta & 210 & 175 & 174,99 & 35 & $\sim 0$ \\
Rokpesta & 125 & 95 & 94,99 & 30 & $\sim 0$ \\
\hline
\end{tabular}

Tabel 3. Base-Stock Level, Laba Maksimum, dan Pendekatan Terbaik Tiap Jenis Produk

\begin{tabular}{ccccc}
\hline $\begin{array}{c}\text { Lifetime } \\
\text { Produk }\end{array}$ & $\begin{array}{c}\text { Jenis } \\
\text { Produk }\end{array}$ & $\begin{array}{c}\text { Base-Stock } \\
\text { Level } \\
\text { (Unit) }\end{array}$ & $\begin{array}{c}\text { Laba } \\
\text { (Rupiah) }\end{array}$ & $\begin{array}{c}\text { Pendekatan } \\
\text { Terbaik }\end{array}$ \\
\hline \multirow{2}{*}{ Pendek } & Batik & 58,88 & 560196,53 & Lognormal \\
& Baju Kotak & 14,75 & 537734,97 & Lognormal \\
& Sifon & 18,89 & 220188,20 & Lognormal \\
& Celana & & & \\
& Panjang & 3972,78 & 1239270,32 & Maksimal \\
Celana 7/8 & 2217,06 & 271315,77 & Maksimal \\
Panjang & Celana 3/4 & 1565,10 & 183679,92 & Maksimal \\
Baju Pesta & 1007,31 & 406308,15 & Maksimal \\
Rok Pesta & 980,68 & 360222,72 & Maksimal \\
\hline
\end{tabular}

\section{Analisis Sensitivitas Laba terhadap Perubahan Coefficient of Variation}

Hasil analisis sensitivitas terhadap perubahan $c v$ permintaan menunjukkan bahwa $c v$ permintaan tidak mempengaruhi keputusan pendekatan terbaik dalam menentukan base-stock level yang menghasilkan maksimum laba. Perubahan standar deviasi permintaan juga sama sekali tidak mempengaruhi keputusan pendekatan terbaik dalam menentukan base-stock level produk lifetime panjang. Hal ini dikarenakan biaya penyimpanan produk mendekati Rp 0,00. Biaya penyimpanan yang jauh lebih kecil daripada biaya stockout menyebabkan dilakukannya pemesanan dalam jumlah yang besar sehingga memungkinkan terjadinya stockout.

Oleh karena itu dapat disimpulkan bahwa penentuan base-stock level yang memaksimumkan laba dapat dilakukan tanpa harus mengetahui pola distribusi permintaan. Pada kasus ini pendekatan lognormal dapat digunakan dalam menentukan 
Tabel 4. Range Salvage Price untuk Pengambilan keputusan

\begin{tabular}{lccc}
\hline \multicolumn{1}{c}{ Jenis } & \multicolumn{3}{c}{ Pendekatan Terbaik (\% Harga beli) } \\
\multicolumn{1}{c}{ Produk } & Normal & Maksimal & Lognormal \\
\hline Batik & $90,03 \leq s<99,37$ & $99,37 \leq s \leq c$ & $0 \leq s<90,03$ \\
Baju Kotak & $96,4,3 \leq s<99,69$ & $99,69 \leq s \leq c$ & $0 \leq s<96,43$ \\
Sifon & $94,55 \leq s<99,64$ & $99,64 \leq s \leq c$ & $0 \leq s<94,55$ \\
Celana & & & \\
Panjang & $96,72 \leq s<99,72$ & $99,72 \leq s \leq c$ & $0 \leq s<96,72$ \\
Celana 7/8 & $96,06 \leq s<99,74$ & $99,74 \leq s \leq c$ & $0 \leq s<96,06$ \\
Celana 3/4 & $96,28 \leq s<99,77$ & $99,77 \leq s \leq c$ & $0 \leq s<96,28$ \\
Baju Pesta & $97,79 \leq s<99,78$ & $99,78 \leq s \leq c$ & $0 \leq s<97,79$ \\
Rok Pesta & $96,47 \leq s<99,66$ & $99,66 \leq s \leq c$ & $0 \leq s<96,47$ \\
\hline
\end{tabular}

base-stock level produk jika salvage price produk ditetapkan mendekati $\mathrm{Rp}$ 0,00 dan pendekatan maksimal dapat digunakan jika salvage price produk ditetapkan mendekati harga beli. Hal tersebut berlaku untuk kondisi dimana biaya stockout besarnya sama dengan laba.

\section{Analisis Sensitivitas Laba terhadap Perubahan Salvage Price}

Range salvage price yang tetap menghasilkan maksimum laba pada tiap pendekatan dipaparkan pada Tabel 4. Tabel 4 menunjukkan bahwa range salvage price untuk pengambilan keputusan pendekatan terbaik berbeda untuk tiap produknya. Penentuan range salvage price untuk pengambilan keputusan diduga dipengaruhi oleh $c v$ dan biaya stockout. Oleh karena itu, dilakukan perhitungan range salvage price yang dapat membantu pengambil keputusan dalam menentukan pendekatan terbaik untuk semua produk.

Sensitivitas salvage price terhadap $c v$ dan biaya stockout (b) dapat dilihat pada Lampiran 1. Pada kondisi biaya stockout diabaikan nilai $c v$ tidak mempengaruhi salvage price. Sedangkan, pada kondisi biaya stockout sebesar persentase dari harga beli, nilai $c v$ mempengaruhi batas bawah dari range salvage price.

Hasil simulasi terhadap setiap nilai $c v$ dan $b$ menunjukkan salvage price yang menghasilkan maksimum laba untuk tiga pendekatan,yaitu: pendekatan Lognormal: $0 \leq$ salvage price $<s_{1}$, Normal: $s_{1} \leq$ salvage price $<s 2$, dan Maksimal: $s_{2} \leq$ salvage price $\leq c$. Hasil detail nilai $s_{1}$ dan $s_{2}$ dapat dilihat pada Lampiran 1.

\section{Analisis Sensitivitas Laba terhadap Perubahan Biaya Stockout}

Sensitivitas biaya stockout terhadap $c v$ dan salvage price dapat dilihat pada Lampiran 2. Pada kondisi salvage price diabaikan nilai $c v$ tidak mempengaruhi biaya stockout. Sedangkan, pada kondisi salvage price sebesar persentase dari harga beli, nilai $c v$ mempengaruhi batas bawah dari range biaya stockout.

Hasil simulasi terhadap nilai $c v$ dan salvage price menunjukkan range biaya stockout pada tiap pendekatan, sebagai berikut: Lognormal: $0 \leq$ biaya stockout $<b_{1}$, Normal: $b_{1} \leq$ biaya stockout $<b_{2}$, dan Maksimal: $b_{2} \leq$ biaya stockout $\leq \infty$. Hasil detail simulasi dapat dilihat pada Lampiran 2.

Pemilihan pendekatan terbaik yang digunakan untuk menentukan base-stock level tidak dipengaruhi oleh jenis distribusi permintaan produk. Faktor yang mempengaruhi pemilihan pendekatan terbaik untuk digunakan dalam menentukan base-stock level suatu produk adalah besarnya salvage price yang ditetapkan dan biaya stockout.

Pada umumnya tingkat ketidakpastian permintaan produk memberikan pengaruh terhadap pemilihan pendekatan terbaik. Pendekatan lognormal merupakan pendekatan terbaik dalam menentukan basestock level produk ketika biaya stockout atau salvage price diabaikan. Akan tetapi untuk kondisi dimana salvage price produk ditetapkan sama dengan harga beli, maka pendekatan maksimal merupakan pendekatan terbaik dalam menentukan base-stock level produk.

\section{Simpulan}

Sebuah model base-stock level untuk dua jenis lifetime pada studi kasus perusahaan garment telah dikembangkan. Analisa sensitivitas menunjukkan biaya stockout dan salvage price merupakan parameter yang paling sensitif. Sedangkan, pola distribusi tidak mempengaruhi penentuan base-stock level yang menghasilkan maksimum laba. Pada studi kasus ini diasumsikan biaya stockout dan salvage price linear terhadap harga perolehan barang. Apabila biaya stockout dan salvage price tidak lagi linear terhadap harga perolehan barang maka kondisi ini akan perlu diadakan penelitian lebih lanjut.

\section{Daftar Pustaka}

1. Ajanta, R., An Inventory Model for Deterioting Items with Price Dependant Demand and TimeVarying Holding Cost. Advance Modeling and Optimization, 10(1), 2008, pp. 25-37.

2. Berling, P., and Martinez-de-Albeniz, V., Optimal Inventory Policies when Purchase Price and Demand are Stochastic.Operations Research, 59(1), 2011, pp. 109-124.

3. Cachon, G. P., and Swinney, R., Purchasing, Pricing, and Quick Response in the Presence of 
Strategic Consumers. Management Science, 55(3), 2009, pp. 497-511.

4. Caro, F., and Gallien, J., Inventory Management of a Fast-Fashion. Retail Network, 58(2), 2010, pp. 257-273.

5. Caro, F., and Martinez-de-Albeniz, V., The Impact of Quick Response in Inventory-Based Competition. Manufacturing and Service Operation Management, 12(3), 2010, pp. 409-429.

6. Chen, Li, and Plambeck, E. L., Dynamic Inventory Management with Learning about the Demand Distribution and Substitution Probability. Manufacturing and Service Operations Management, 10(2), 2008, pp. 236-256.

7. Gallego, G., Katircioglu, K, and Ramachandran, B., Inventory Management under Highly Uncertain Demand. Operations Research Letters, 35, 2007, pp. 281-289.

8. Jinn, T., Maw, S.C., Hui, L.Y., and Yuchung, J.W., Deterministic Lot-Size Inventory Models with Shortages and Deterioration for Fluctuating Demand. Demand. Operations Research Letters, 35, 1999, pp. 65-72.

9. Tersine, R. J. Principles of Inventory and Materials Management, $4^{\text {th }}$ ed. New Jersey: Prentice-Hall International, 1994.

10. Vaagen, H., and Wallace, S. W., Product Variety Arising from Hedging in the Fashion Supply Chains. International Journal for Production Economics, 114(2), 2008, pp. 431-455.

11. Webster, S. W., and Kevin Z., Ordering and Pricing Policies in a Manufacturing and Distribution Supply Chain for Fashion Products. International Journal for Production Economics, 114 (2), 2008, pp. 476-486.

12. Widyadana. A. G., and Wee, M. W., The Production Inventory Models for Deteriorating Items with Stochastic Machine Unavailability Time, Lost Sales and Price-Dependent Demand. Jurnal Teknik Industri, 12(2), 2010, pp. 61-68. 
Lampiran 1. Nilai $s_{1}$ dan $s_{2}$ untuk Pengambilan Keputusan

\begin{tabular}{|c|c|c|c|c|c|c|c|c|c|c|c|c|c|c|c|c|c|c|c|c|c|}
\hline \multirow[b]{2}{*}{ cv } & \multirow{2}{*}{$\begin{array}{c}b=0 \\
s_{1}\end{array}$} & \multicolumn{2}{|c|}{$b=10 \% c$} & \multicolumn{2}{|c|}{$b=20 \% c$} & \multicolumn{2}{|c|}{$b=30 \% c$} & \multicolumn{2}{|c|}{$b=40 \% c$} & \multicolumn{2}{|c|}{$b=50 \% c$} & \multicolumn{2}{|c|}{$b=60 \% c$} & \multicolumn{2}{|c|}{$b=70 \% c$} & \multicolumn{2}{|c|}{$b=80 \% c$} & \multicolumn{2}{|c|}{$b=90 \% c$} & \multicolumn{2}{|c|}{$b=c$} \\
\hline & & $s_{1}$ & $s_{2}$ & $s_{1}$ & $s_{2}$ & $s_{1}$ & $s_{2}$ & $s_{1}$ & $s_{2}$ & $s_{1}$ & $s_{2}$ & $s_{1}$ & $s_{2}$ & $s_{1}$ & $s_{2}$ & $s_{1}$ & $s_{2}$ & $s_{1}$ & $s_{2}$ & $s_{1}$ & $s_{2}$ \\
\hline 0,1 & & 99,46 & & 98,92 & & 98,38 & & 97,84 & & 97,30 & & 96,76 & & 96,22 & & 95,68 & & 95,13 & & 94,59 & \\
\hline 0,2 & & 99,44 & & 98,87 & & 98,30 & & 97,73 & & 97,16 & & 96,59 & & 96,02 & & 95,45 & & 94,88 & & 94,31 & \\
\hline 0,3 & & 99,39 & & 98,78 & & 98,16 & & 97,55 & & 96,93 & & 96,32 & & 95,70 & & 95,04 & & 94,48 & & 93,86 & \\
\hline 0,4 & & 99,33 & & 98,66 & & 97,98 & & 97,31 & & 96,63 & & 95,96 & & 95,28 & & 94,61 & & 93,93 & & 93,26 & \\
\hline 0,5 & & 99,26 & & 98,51 & & 97,76 & & 97,02 & & 96,27 & & 95,52 & & 94,78 & & 94,03 & & 93,28 & & 92,54 & \\
\hline 0,6 & & 99,18 & & 98,35 & & 97,52 & & 96,69 & & 95,87 & & 95,04 & & 94,21 & & 93,38 & & 92,55 & & 91,73 & \\
\hline 0,7 & & 99,09 & & 98,18 & & 97,26 & & 96,35 & & 95,43 & & 94,52 & & 93,60 & & 92,69 & & 91,77 & & 90,86 & \\
\hline 0,8 & & 99,00 & & 98,00 & & 97,21 & & 95,99 & & 94,98 & & 93,98 & & 92,97 & & 91,97 & & 90,96 & & 89,96 & \\
\hline 0,9 & & 98,91 & & 97,82 & & 96,72 & & 95,63 & & 94,53 & & 93,44 & & 92,34 & & 91,25 & & 90,16 & & 89,06 & \\
\hline 1,0 & & 98,82 & & 97,64 & & 96,46 & & 95,28 & & 94,09 & & 92,91 & & 91,73 & & 90,55 & & 89,36 & & 89,30 & \\
\hline 1,1 & & 98,74 & & 97,47 & & 96,21 & & 94,94 & & 93,67 & & 92,41 & & 91,14 & & 89,88 & & 88,61 & & 87,34 & \\
\hline 1,2 & & 98,66 & & 97,31 & & 95,97 & & 94,62 & & 93,28 & & 91,93 & & 90,59 & & 89,24 & & 87,90 & & 86,55 & \\
\hline 1,3 & & 98,59 & & 97,17 & & 95,75 & & 94,33 & & 92,92 & & 91,50 & & 90,08 & & 88,66 & & 87,24 & & 85,82 & \\
\hline 1,4 & & 98,52 & & 97,04 & & 95,55 & & 94,07 & & 92,58 & & 91,10 & & 89,61 & & 88,13 & & 86,65 & & 85,16 & \\
\hline 1,5 & 0.00 & 98,46 & 39 & 96,92 & 78 & 95,38 & 67 & 93,83 & 9,5 & 92,29 & 45 & 90,75 & & 89,20 & & 87,66 & 2 & 86,12 & 9.01 & 84,57 & 98,90 \\
\hline 1,6 & & 98,41 & & 96,82 & & 95,22 & & 93,63 & & 92,03 & & 90,44 & & 88,84 & & 87,25 & & 85,65 & & 84,06 & 98, \\
\hline 1,7 & & 98,37 & & 96,73 & & 95,09 & & 93,45 & & 91,81 & & 90,17 & & 88,53 & & 86,90 & & 85,26 & & 83,62 & \\
\hline 1,8 & & 98,33 & & 96,65 & & 94,98 & & 93,30 & & 91,63 & & 89,95 & & 88,28 & & 86,60 & & 84,93 & & 83,25 & \\
\hline 1,9 & & 98,30 & & 96,36 & & 94,89 & & 93,19 & & 91,48 & & 89,78 & & 88,08 & & 86,37 & & 84,67 & & 82,96 & \\
\hline 2,0 & & 98,28 & & 96,55 & & 94,83 & & 93,10 & & 91,38 & & 89,65 & & 87,92 & & 86,19 & & 84,47 & & 82,74 & \\
\hline 2,1 & & 98,26 & & 96,52 & & 94,78 & & 93,04 & & 91,30 & & 89,56 & & 87,82 & & 86,08 & & 84,33 & & 82,59 & \\
\hline 2,2 & & 98,26 & & 96,51 & & 94,76 & & 93,01 & & 91,26 & & 89,51 & & 87,63 & & 86,01 & & 84,26 & & 82,51 & \\
\hline 2,3 & & 98,25 & & 96,50 & & 94,75 & & 93,00 & & 91,25 & & 89,49 & & 87,74 & & 85,99 & & 84,24 & & 82,49 & \\
\hline 2,4 & & 98,26 & & 96,51 & & 94,76 & & 93,01 & & 91,27 & & 89,52 & & 87.77 & & 86,02 & & 84,27 & & 82,53 & \\
\hline 2,5 & & 98,27 & & 96,53 & & 94,79 & & 93,05 & & 91,31 & & 89,58 & & 87,84 & & 86,10 & & 84,36 & & 82,62 & \\
\hline 2,6 & & 98,28 & & 96,56 & & 94,83 & & 93,11 & & 91,39 & & 89,66 & & 87,94 & & 86,22 & & 84,49 & & 82,77 & \\
\hline 2,7 & & 98,30 & & 96,60 & & 94,89 & & 93,19 & & 91,48 & & 89,78 & & 88,08 & & 86,37 & & 84,67 & & 82,97 & \\
\hline 2,8 & & 98,33 & & 96,65 & & 94,97 & & 93,29 & & 91,61 & & 89,93 & & 88,25 & & 86,59 & & 84,89 & & 83,21 & \\
\hline 2,9 & & 98,35 & & 96,70 & & 95,05 & & 93,40 & & 91,75 & & 90,10 & & 88,45 & & 86,80 & & 85,15 & & 83,50 & \\
\hline 3,0 & & 98,39 & & 96,77 & & 95,15 & & 93,53 & & 91,92 & & 90,30 & & 88,68 & & 87,06 & & 85,44 & & 83,83 & \\
\hline
\end{tabular}

Lognormal: $0 \leq$ salvage price $<s_{1}$

Normal: $s_{1} \leq$ salvage price $<s \quad$ Maksimal: $s_{2} \leq$ salvage price $\leq c$

Lampiran 2. Nilai $b_{1}$ dan $b_{2}$ untuk Pengambilan Keputusan

\begin{tabular}{|c|c|c|c|c|c|c|c|c|c|c|c|c|c|c|c|c|c|c|c|c|}
\hline \multirow{2}{*}{\multicolumn{2}{|c|}{$\begin{array}{cc} & s=0 \\
c v \quad b_{1}\end{array}$}} & \multicolumn{2}{|c|}{$s=10 \% c$} & \multicolumn{2}{|c|}{$s=20 \% c$} & \multicolumn{2}{|c|}{$s=30 \% c$} & \multicolumn{2}{|c|}{$s=40 \% c$} & \multicolumn{2}{|c|}{$s=50 \% c$} & \multicolumn{2}{|c|}{$s=60 \% c$} & \multicolumn{2}{|c|}{$s=70 \% c$} & \multicolumn{2}{|c|}{$s=80 \% c$} & \multicolumn{2}{|c|}{$s=90 \% c$} & \multirow{2}{*}{$\begin{array}{c}s=c \\
b_{2}\end{array}$} \\
\hline & & $b_{1}$ & $b_{2}$ & $b_{1}$ & $B_{2}$ & $b_{1}$ & $b_{2}$ & $b_{1}$ & $b_{2}$ & $b_{1}$ & $b_{2}$ & $b_{1}$ & $b_{2}$ & $b_{1}$ & $b_{2}$ & $b_{1}$ & $b_{2}$ & $b_{1}$ & $b_{2}$ & \\
\hline 0,1 & & 16,627 & & 14,780 & & 12,932 & & 11,085 & & 9,238 & & 7,390 & & 5,543 & & 3,695 & & 1,848 & & \\
\hline 0,2 & & 15,813 & & 14,327 & & 12,479 & & 10,632 & & 8,784 & & 7,028 & & 5,271 & & 3,514 & & 1,757 & & \\
\hline 0,3 & & 14,650 & & 13,462 & & 11,614 & & 9,767 & & 8,139 & & 6,512 & & 4,884 & & 3,256 & & 1,628 & & \\
\hline 0,4 & & 13,344 & & 11,862 & & 10,379 & & 8,896 & & 7,414 & & 5,931 & & 4,448 & & 2,966 & & 1,483 & & \\
\hline 0,5 & & 12,054 & & 10,715 & & 9,375 & & 8,036 & & 6,697 & & 5,358 & & 4,018 & & 2,679 & & 1,340 & & \\
\hline 0,6 & & 10,872 & & 9,664 & & 8,456 & & 7,248 & & 6,040 & & 4,832 & & 3,624 & & 2,416 & & 1,208 & & \\
\hline 0,7 & & 9,841 & & 8,747 & & 7,653 & & 6,560 & & 5,467 & & 4,374 & & 3,280 & & 2,187 & & 1,094 & & \\
\hline 0,8 & & 8,962 & & 7,966 & & 6,970 & & 5,975 & & 4,979 & & 3,983 & & 2,988 & & 1,992 & & 0,996 & & \\
\hline 0,9 & & 8,226 & & 7,312 & & 6,398 & & 5,484 & & 4,570 & & 3,656 & & 2,742 & & 1,828 & & 0,914 & & \\
\hline 1,0 & & 7,615 & & 6,769 & & 5,923 & & 5,077 & & 4,231 & & 3,385 & & 2,539 & & 1,693 & & 0,847 & & \\
\hline 1,1 & & 7,109 & & 6,319 & & 5,530 & & 4,740 & & 3,950 & & 3,160 & & 2,370 & & 1,580 & & 0,790 & & \\
\hline 1,2 & & 6,692 & & 5,948 & & 5,205 & & 4,461 & & 3,718 & & 2,974 & & 2,231 & & 1,488 & & 0,744 & & \\
\hline 1,3 & & 6,348 & & 5,643 & & 4,937 & & 4,232 & & 3,527 & & 2,821 & & 2,116 & & 1,411 & & 0,706 & & \\
\hline 1,4 & & 6,065 & & 5,391 & & 4,717 & & 4,043 & & 3,370 & & 2,696 & & 2,022 & & 1,348 & & 0,674 & & \\
\hline 1,5 & $\infty$ & 5,833 & 81401 & 5,185 & 72356 & 4,537 & 63.313 & 3,889 & 54267 & 3,241 & 45223 & 2,593 & 36178 & 1,945 & 27134 & 1,297 & 18089 & 0,649 & 045 & 0 \\
\hline 1,6 & $\infty$ & 5,645 & 81,401 & 5,018 & /Z,300 & 4,463 & 03,313 & 3,764 & 54,206 & 3,136 & $40,2 Z 3$ & 2,509 & $0,1 / 8$ & 1,882 & 21,134 & 1,255 & 18,089 & 0,628 & り & U \\
\hline 1,7 & & 5,494 & & 4,883 & & 4,273 & & 3,663 & & 3,052 & & 2,442 & & 1,832 & & 1,221 & & 0,611 & & \\
\hline 1,8 & & 5,374 & & 4,777 & & 4,180 & & 3,584 & & 2,986 & & 2,389 & & 1,792 & & 1,195 & & 0,598 & & \\
\hline 1,9 & & 5,282 & & 4,696 & & 4,109 & & 3,522 & & 2,935 & & 2,348 & & 1,761 & & 1,174 & & 0,587 & & \\
\hline 2,0 & & 5,215 & & 4,636 & & 4,056 & & 3,477 & & 2,898 & & 2,318 & & 1,739 & & 1,159 & & 0,580 & & \\
\hline 2,1 & & 5,170 & & 4,596 & & 4,021 & & 3,447 & & 2,873 & & 2,298 & & 1,724 & & 1,149 & & 0,575 & & \\
\hline 2,2 & & 5,145 & & 4,574 & & 4,002 & & 3,431 & & 2,859 & & 2,287 & & 1,715 & & 1,144 & & 0,572 & & \\
\hline 2,3 & & 5,139 & & 4,568 & & 3,997 & & 3,426 & & 2,855 & & 2,284 & & 1,713 & & 1,142 & & 0,571 & & \\
\hline 2,4 & & 5,151 & & 4,578 & & 4,006 & & 3,434 & & 2,862 & & 2,289 & & 1,717 & & 1,145 & & 0,573 & & \\
\hline 2,5 & & 5,111 & & 4,603 & & 4,028 & & 3,453 & & 2,877 & & 2,302 & & 1,727 & & 1,151 & & 0,576 & & \\
\hline 2,6 & & 5,223 & & 4,643 & & 4,063 & & 3,482 & & 2,902 & & 2,322 & & 1,741 & & 1,161 & & 0,581 & & \\
\hline 2,7 & & 5,284 & & 4,697 & & 4,110 & & 3,523 & & 2,936 & & 2,349 & & 1,762 & & 1,175 & & 0,588 & & \\
\hline 2,8 & & 5,361 & & 4,765 & & 4,170 & & 3,574 & & 2.979 & & 2,383 & & 1,787 & & 1,192 & & 0,596 & & \\
\hline 2,9 & & 5,454 & & 4,848 & & 4,242 & & 3,636 & & 3,030 & & 2,424 & & 1,818 & & 1,212 & & 0,606 & & \\
\hline 3 & & 5,565 & & 4,947 & & 4,328 & & 3,710 & & 3,092 & & 2,474 & & 1,855 & & 1,237 & & 0,619 & & \\
\hline
\end{tabular}

